\title{
Multifocal osteonecrosis and osteomyelitis in a liver transplant recipient
}

\author{
Karaciğer nakli yapılan bir hastada multifokal osteonekroz ve osteomiyelit
}

\author{
Mehtap Üçer, ${ }^{1}$ Neslihan Yılmaz, ${ }^{2}$ Yonca Çağatay, ${ }^{3}$ Mari Benli, ${ }^{4}$ Levent Ulusoy, ${ }^{5}$ Murat Akyıldız, ${ }^{6}$ Şule Yavuz ${ }^{2}$ \\ ${ }^{1}$ Department of Internal Medicine, Medical Faculty of İstanbul Bilim University, İstanbul, Turkey \\ ${ }^{2}$ Department of Rheumatology, Medical Faculty of İstanbul Bilim University, İstanbul, Turkey \\ ${ }^{3}$ Department of Rheumatology, İstanbul Florence Nightingale Hospital, İstanbul, Turkey \\ ${ }^{4}$ Department of Nuclear Medicine, İstanbul Florence Nightingale Hospital, İstanbul, Turkey \\ ${ }^{5}$ Department of Radiology, İstanbul Florence Nightingale Hospital, Istanbul, Turkey \\ ${ }^{6}$ Department of Gastroenterology, İstanbul Florence Nightingale Hospital, İstanbul, Turkey
}

\begin{abstract}
Osteonecrosis is the destruction of bone as a result of temporary or permanent cessation of blood supply to the bones. Trauma, drugs, infections, hypercoagulability and solid organ transplantation are the most common causes. Osteonecrosis has been reported in many case series after renal, liver and cardiac transplantation; mainly in areas adjacent to the joints, especially on hip. Here, we are reporting multifocal osteonecrosis with osteomyelitis including diaphyseal region of the tibia in a patient with liver transplantation.

Keywords: Infection; liver transplantation; osteonecrosis.
\end{abstract}

öz

Osteonekroz (ON), kemiklerin kanlanmasının kalıcı ya da geçici olarak kesilmesi ile meydana gelen kemik yıkımıdır. En sık nedenleri arasında; travma, ilaçlar, enfeksiyonlar, hiperkoagülabilite ve solid organ nakli sayılabilir. Bir çok olgu serisinde, böbrek, karaciğer ve kalp nakli sonrasında özellikle kalçada olmak üzere, eklem çevresinde osteonekroz gelişebildiği bildirilmiştir. Bu makalede karaciğer nakli sonrasında ortaya çıkan, tibianın diafiz bölgesi dahil olmak üzere multifokal yerleşimli, osteomiyelitin eşlik ettiği bir osteonekroz olgusu sunuldu.

Anahtar sözcükler: Enfeksiyon; karaciğer transplantasyonu; osteonekroz.

Osteonecrosis $(\mathrm{ON})$ is a disease resulting from temporary or permanent loss of blood supply to the bones. The most common causes of $\mathrm{ON}$ are; trauma, drugs, infections, hypercoagulable conditions and solid organ transplantation. ${ }^{[1]}$ Osteonecrosis has been reported in many case series after renal, liver and cardiac transplantation; mainly in areas adjacent to the joints, especially on hip. ${ }^{[1-7]}$ Here, we are reporting multifocal $\mathrm{ON}$ with osteomyelitis including diaphyseal region of the tibia in a patient with liver transplantation.

\section{CASE REPORT}

A 42-year-old male patient, who underwent liver transplantation due to $\mathrm{HBV}$-associated liver cirrhosis two years ago, was hospitalized on April 2013 with high grade fever, chills and abdominal pain. In his history, he had stenosis of biliary duct anastomosis and, percutaneous biliary cholangiography and balloon dilatation with internal drainage were performed four days ago. At the presentation, he was under methylprednisolone $8 \mathrm{mg} / \mathrm{day}$, tacrolimus 
$2 \mathrm{mg} /$ day, entecavir $0.5 \mathrm{mg} /$ day, ibandronic acid $150 \mathrm{mg} / \mathrm{month}$ and calcium $1000 \mathrm{mg} /$ day. In addition he was on eltrombopag $50 \mathrm{mg} /$ day therapy due to immune thrombocytopenia since 2011.

At admission to our clinic blood pressure was 125/75 $\mathrm{mmHg}$, pulse was $96 \mathrm{bpm}$ and temperature was $38.5{ }^{\circ} \mathrm{C}$. Physical examination showed splenomegaly, abdominal tenderness and scleral icterus. Upon admission, acute phase reactants were elevated with a white blood cell count (WBC): $12,470 / \mathrm{mm}^{3}$ with raised neutrophils at $77 \%$, C-reactive protein (CRP) $23 \mathrm{mg} / \mathrm{dL}$. Blood chemistry showed cholestasis with alkaline phosphatase: $386 \mathrm{IU} / \mathrm{L}$, gamma glutamyl transferase: $83 \mathrm{IU} / \mathrm{L}$, total bilirubin: $1.57 \mathrm{mg} / \mathrm{dL}$ and direct bilirubin: $1.05 \mathrm{mg} / \mathrm{dL}$. Hepatitis B surface antigen was negative. Sample from biliary fluid obtained from percutaneous stent was revealed that Klebsiella and Enterococcus microorganisms. Intravenous antibiotic therapy with cefoperazone/sulbactam $2 \mathrm{~g}$, bid was started for cholangitis. This was followed up by a course of oral co-amoxiclav with ciprofloxacin following discharge.

On May 2013, he presented again with high grade fever and acute swelling on left knee and ankle with pain until 10 days prior to admission. His laboratory results were as follows; Hemoglobin: $9.7 \mathrm{~g} / \mathrm{dL}, \mathrm{WBC}: 8,340 / \mathrm{mm}^{3}$ with raised neutrophils at $76.3 \%$, platelet: $21,000 / \mathrm{mm}^{3}$, CRP: $1.78 \mathrm{mg} / \mathrm{dL}$, erythrocyte sedimentation rate (ESR): $27 \mathrm{~mm} / \mathrm{h}$. Blood chemistry showed normal hepatic and renal function. The antinuclear antibody, rheumatoid factor and anticardiolipin antibodies were negative. Effusions of the left knee and left ankle joint were aspirated. No organism was seen by using gram staining on the microscope and cultures for bacteria were found to be negative. Intravenous cefoperazone/ sulbactam $2 \mathrm{~g}$ bid, was started again for 10 days. Fever decreased, joint pain and effusion were resolved and CRP levels tended to decrease (1.41 mg/dL). The patient was discharged with oral co-amoxiclav therapy.

One week later, he was admitted to Rheumatology outpatient clinic again with an increase in pain and swelling on both left knee and ankle. At the examination, huge swelling, warmth and redness were observed on his left knee. Acute phase reactants were elevated with a WBC: 11,660/mm ${ }^{3}$, CRP: $8.36 \mathrm{mg} / \mathrm{dL}$. He was hospitalized again with suspicion of septic arthritis. The blood, urine culture, biliary and joint fluid samples from left knee were taken. Synovial fluid aspiration yielded WBC: $6,800 / \mathrm{mm}^{3}$, no microorganism was seen on microscopy and culture for bacteria was found to be negative. Intravenous ciprofloxacin $400 \mathrm{mg}$ twice daily and teicoplanin $400 \mathrm{mg}$ once a daily were started as empirically. Blood and urine cultures were sterile, however Klebsiella pneumoniae was cultured again from biliary fluid. Piperacillin/tazobactam $4.5 \mathrm{~g}$, tid was added to main therapy according to antibiogram. Although CRP levels decrease to $0.96 \mathrm{mg} / \mathrm{dL}$, his left knee and ankle pain with swelling persisted. The knee and ankle MR imaging were performed in order to rule out osteomyelitis. In left knee MR images, multiple osteonecrosis area was observed on distal femur, proximal tibia and patella. In left ankle images diaphysial bone infarct on distal tibia was seen (Figure 1). There was no any finding of osteomyelitis in MR images at that time.

Two months later the patient was admitted to the hospital due to worsening of his knee pain. Scintigraphy imaging was performed at that time. At whole body 99mTc-labeled hexamethylpropyleneamine oxime (99mTc-HMPAO) leukocyte scintigraphy, there were mildly increased osteoblastic activities at left proximal and distal tibia (Figure 2). In addition 99mTc-MDP three-phase bone scan images showed, increased soft tissue perfusion and activity at both perfusion and blood pool phases, in addition increased osteoblastic activity at bone phase on left knee and left ankle. These findings were compatible with inflammation and had been interpreted as infection. Due to uncontrolled bacterial infection; osteomyelitis was thought to be added over areas of osteonecrosis, during his follow-up.

\section{DISCUSSION}

The number of liver transplantations worldwide has increased dramatically over the past decade. Osteonecrosis associated with solid organ transplantation has been reported in many case series and, generally is localized at femoral head. ${ }^{[2]}$ Although the prevalence of $\mathrm{ON}$ after renal transplantation has been reported to be $5-24 \%,{ }^{[2]}$ 

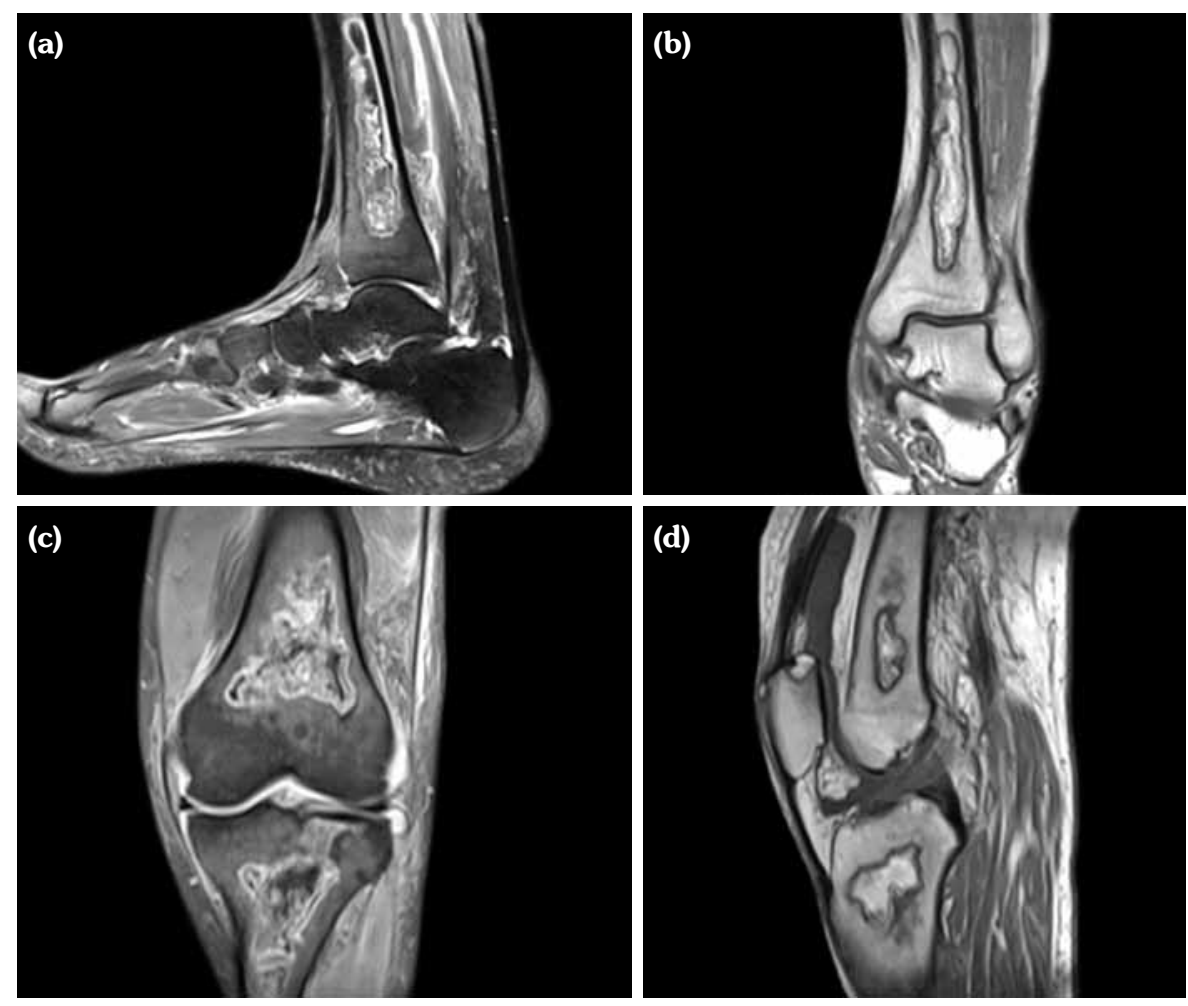

Figure 1. Magnetic resonance imaging of left ankle and left knee. (a) Sagital fat suppressed $\mathrm{T}_{2}$-weighted image and (b) coronal $\mathrm{T}_{1}$-weighted image of left ankle. (c) Coronal fat suppressed $\mathrm{T}_{2}$-weighted image and (d) sagital $\mathrm{T}_{1}$-weighted image of left knee. Images show multifocal area of medullary bone infarcts at patella, distal femur and proximal tibia and serpiginous area of medullary bone infarct at distal metaphysis of tibia.

relatively lower prevalence of $\mathrm{ON}$ is observed after liver transplantation $2-8.2 \% \%^{[1,4]}$ This difference may be explained in some way by the underlying metabolic problems associated with chronic renal failure. ${ }^{[1]}$ The risk factors of $\mathrm{ON}$ in liver transplant recipients have been reported as osteoporosis, hypercoagulability, drugs especially corticosteroid therapy, smoking, alcohol abuse, trauma etc. However, association between, age, Child score (in cirrhotic patients), biochemical parameters and ON have not been found ${ }^{[1,3]}$ In addition, decreased hip and knee ON incidence has reported in patients treated with cyclosporine and tacrolimus which might reflect the steroid sparing effect of these drugs. ${ }^{[6]}$

Drugs, especially steroid therapy are important risk factors of ON. The most commonly affected sites of $\mathrm{ON}$ in patients on steroid therapy are femoral and humeral heads. ${ }^{[8]}$ In addition, knee joints, talus, lunate and scaphoid bones are susceptible to ischemic necrosis because of their geometry, nutritional characteristics and hemodynamic features. Also is not clear whether the risk of $\mathrm{ON}$ is related to cumulative steroid dosage or not dose dependent..$^{[1,8-12]}$ In the literature, some case series showed that corticosteroid associated ON could be related to individual response (e.g. changes in steroid metabolism, hypercoagulable, hypofibrinolysis and genetic factors)..$^{[1,2]}$ In contrast, many different investigators suggest that steroidinduced osteonecrosis is dose dependent. ${ }^{[1,11-13]}$ In our liver transplantation center, steroid usually tapered in three to six months. However, our patient has a history of high dose steroid usage for a long time due to immune thrombocytopenia. Although liver transplantation is known as a risk factor of $\mathrm{ON}$, high cumulative steroid dosage may have contributed to $\mathrm{ON}$ in our case.

Osteopenia is another risk factor for $\mathrm{ON}^{[4]}$ On the other hand, prolonged therapy with bisphosphonates, adversely leads to $\mathrm{ON}$ of the jaws in some patients. ${ }^{[14]}$ Bisphosphonates associated 
(a)

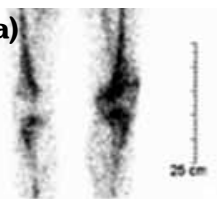

(b)

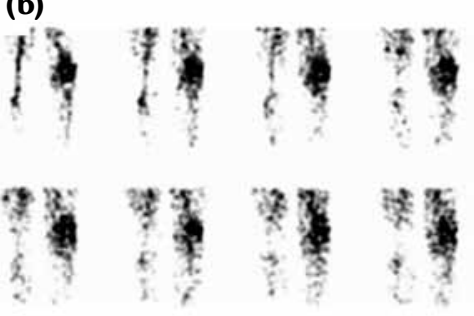

(c)

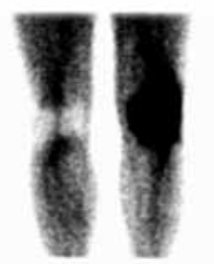

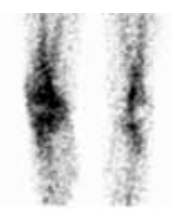

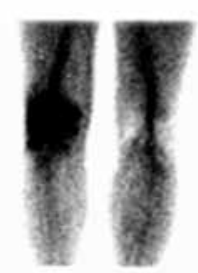

(d)

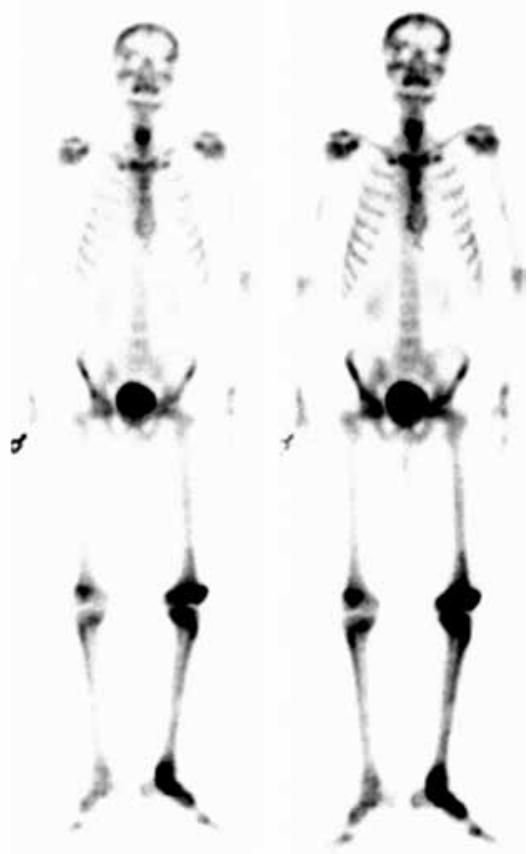

Figure 2. (a) Whole body leukocyte scintigraphy: compared to the symmetric side increased osteoblastic activity on the left knee, (b) Three-phase bone scintigraphy, perfusion phase: increased soft tissue perfusion and activity at left knee (c) Three-phase bone scintigraphy, blood pool-phase: increased osteoblastic activity at left knee (d) Three phase bone scan late-phase: increased activity at left knee and left ankle.

ON rarely occurs in the long bones, only one case was reported on zoledronic acid therapy. ${ }^{[15]}$ In a study, 20 cases of bisphosphonate-related osteonecrosis were reviewed and 16 alendronate and four ibandronate usage were reported. ${ }^{[14]}$ Our patient was using ibandronate for two years for osteoporosis, and this could be another triggering risk factor of $\mathrm{ON}$.

Although there were some case reports regarding coexistence of avascular necrosis and osteomyelitis, we have not any concrete proof that one of these factors might be a risk factor for the other one. It is believed that there is an association between preexisting avascular necrosis and osteomyelitis. Patients with SLE, or HIV infection, or sickle cell disease, or solid organ transplantation are inclined to develop avascular necrosis because they might use steroid and increased risk factors for thrombosis. ${ }^{[16,17]}$ However, avascular necrosis is a risk factor for septic arthritis regardless of the underlying disorder. ${ }^{[18,19]}$ Septic arthritis has been reported to occur in during the follow-up osteonecrosis especially immunocompromised patient due to lupus or organ transplantation. ${ }^{[20-23]}$ On the other hand, in situations with bacteriemia, hematogenously distributed bacteria possessing the specific ability to bind to bone collagen and, has capacity to trigger osteomyelitis. ${ }^{[24,25]}$ The bacteria adhere directly to the cartilage matrix and they form obstructive emboli in the metaphyseal vasculature causes local ischemia and necrosis. ${ }^{[24-26]}$ In our patient uncontrolled biliary system infection may possibly lead to osteonecrosis and osteomyelitis as a result of hematogenous dissemination of bacteria.

Here, we reported a patient with multifocal and exceptional location of osteonecrosis and osteomyelitis. Although $\mathrm{ON}$ is well known complication of after transplantation and steroid therapy, it generally located at femur head. As in our case; $\mathrm{ON}$ is rarely place on diaphyseal region of long bone with multifocal location, this 
situation may be associated with the presence of uncontrolled infection.

\section{Declaration of conflicting interests}

The authors declared no conflicts of interest with respect to the authorship and/or publication of this article.

\section{Funding}

The authors received no financial support for the research and/or authorship of this article.

\section{REFERENCES}

1. Li H, Zhang J, He JW, Wang K, Wang GS, Jiang N, et al. Symptomatic osteonecrosis of the femoral head after adult orthotopic liver transplantation. Chin Med $\mathrm{J}$ (Engl) 2012;125:2422-6.

2. Lieberman JR, Scaduto AA, Wellmeyer E. Symptomatic osteonecrosis of the hip after orthotopic liver transplantation. J Arthroplasty 2000;15:767-71.

3. Guichelaar MM, Schmoll J, Malinchoc M, Hay JE. Fractures and avascular necrosis before and after orthotopic liver transplantation: long-term follow-up and predictive factors. Hepatology 2007;46:1198-207.

4. Papagelopoulos PJ, Hay JE, Galanis EC, Morrey BF. Total joint arthroplasty in orthotopic liver transplant recipients. J Arthroplasty 1996;11:889-92.

5. Horiuchi H, Hashikura Y, Hisa K, Saito N, Ikegami $\mathrm{T}$, Nakazawa $\mathrm{Y}$, et al. Osteonecrosis of the femoral head in Japanese adults after liver transplantation: a preliminary report. J Orthop Sci 2004;9:119-21.

6. Takao M, Sakai T, Nishii T, Yoshikawa H, Takahara S, Sugano N. Incidence and predictors of osteonecrosis among cyclosporin- or tacrolimus-treated renal allograft recipients. Rheumatol Int 2011;31:165-70.

7. Bradbury G, Benjamin J, Thompson J, Klees E, Copeland J. Avascular necrosis of bone after cardiac transplantation. Prevalence and relationship to administration and dosage of steroids. $\mathrm{J}$ Bone Joint Surg [Am] 1994;76:1385-8.

8. Powell C, Chang C, Naguwa SM, Cheema G, Gershwin ME. Steroid induced osteonecrosis: An analysis of steroid dosing risk. Autoimmun Rev 2010;9:721-43.

9. Lieberman JR, Scaduto AA, Wellmeyer E. Symptomatic osteonecrosis of the hip after orthotopic liver transplantation. J Arthroplasty 2000;15:767-71.

10. Lieberman JR, Roth KM, Elsissy P, Dorey FJ, Kobashigawa JA. Symptomatic osteonecrosis of the hip and knee after cardiac transplantation. J Arthroplasty 2008;23:90-6.

11. Guichelaar MM, Schmoll J, Malinchoc M, Hay JE. Fractures and avascular necrosis before and after orthotopic liver transplantation: long-term follow-up and predictive factors. Hepatology 2007;46:1198-207.
12. Shibatani M, Fujioka M, Arai Y, Takahashi K, Ueshima $\mathrm{K}$, Okamoto M, et al. Degree of corticosteroid treatment within the first 2 months of renal transplantation has a strong influence on the incidence of osteonecrosis of the femoral head. Acta Orthop 2008;79:631-6.

13. Abbott KC, Koff J, Bohen EM, Oglesby RJ, Agodoa LY, Lentine $\mathrm{KL}$, et al. Maintenance immunosuppression use and the associated risk of avascular necrosis after kidney transplantation in the United States. Transplantation 2005;79:330-6.

14. Diniz-Freitas M, López-Cedrún JL, FernándezSanromán J, García-García A, Fernández-Feijoo J, Diz-Dios P. Oral bisphosphonate-related osteonecrosis of the jaws: Clinical characteristics of a series of 20 cases in Spain. Med Oral Patol Oral Cir Bucal 2012;17:751-8.

15. Gupta S, Jain P, Kumar P, Parikh PM. Zoledronic acid induced osteonecrosis of tibia and femur. Indian J Cancer 2009;46:249-50.

16. Blacksin MF, Kloser PC, Simon J. Avascular necrosis of bone in human immunodeficiency virus infected patients. Clin Imaging 1999;23:314-8.

17. Blacksin MF, Finzel KC, Benevenia J. Osteomyelitis originating in and around bone infarcts: giant sequestrum phenomena. AJR Am J Roentgenol 2001:176:387-91.

18. Markov G, Dobro J, Shankman S, Belmont HM. Enterococcal arthritis with avascular necrosis in a lupus patient. Br J Rheumatol 1996;35:595-7.

19. Phillips FM, Pottenger LA. Acute septic arthritis in chronic osteonecrosis of the hip. $\mathrm{J}$ Rheumatol 1988;15:1713-6.

20. Lee YK, Lee YJ, Ha YC, Kim KC, Koo KH. Septic arthritis of the hip in patients with femoral head osteonecrosis. Arch Orthop Trauma Surg 2011;131:1585-90.

21. Galindo M, Mateo I, Pablos JL. Multiple avascular necrosis of bone and polyarticular septic arthritis in patients with systemic lupus erythematosus. Rheumatol Int 2005;25:72-6.

22. Phillips FM, Pottenger LA. Acute septic arthritis in chronic osteonecrosis of the hip. $\mathrm{J}$ Rheumatol 1988;15:1713-6.

23. Habermann ET, Friedenthal RB. Septic arthritis associated with avascular necrosis of the femoral head. Clin Orthop Relat Res 1978;134:325-31.

24. Wideman RF, Prisby RD. Bone circulatory disturbances in the development of spontaneous bacterial chondronecrosis with osteomyelitis: a translational model for the pathogenesis of femoral head necrosis. Front Endocrinol (Lausanne) 2013;3:183.

25. Smeltzer MS, Gillaspy AF. Molecular pathogenesis of staphylcoccal osteomyelitis. Poult Sci 2000;79:1042-9.

26. McNamee PT, Smyth JA. Bacterial chondronecrosis with osteomyelitis ('femoral head necrosis') of broiler chickens: a review. Avian Pathol 2000;29:253-70. 